\title{
Joint Effect of Supply Chain Process Integration Capabilities, Information Technology Infrastructure and Government Policy on Supply Chain Performance of Public Universities in Kenya
}

\author{
Judith Nelima Wasike Milimo $^{1} \quad$ Evans Vidija Sagwa $^{2} \quad$ Maurice Matendechere Sakwa ${ }^{3}$ \\ 1.PhD Candidate, School of Business and Management Studies, Technical University of Kenya, P. O. Box \\ 52428-00200 Nairobi, Kenya \\ 2.School of Business and Management Studies, Technical University of Kenya \\ 3.College of Human Resource Development, Jomo Kenyatta University of Agriculture and Technology, Nairobi \\ Kenya
}

Corresponding Author: Judith Nelima Wasike Milimo.

Research conducted under Research Authorization Permit NACOSTI/P/IT/97613/18539 of 20 th September, 2017 issued by National Commission for Science Technology and Innovation, Kenya. The Technical University of Kenya sponsored the PhD Course.

\section{Abstract}

Although the individual effects of supply chain process integration capabilities, information technology infrastructure and government policy on performance have to some extent been researched on, the joint effect has not been subjected to research. The objective of the study was to establish the joint effect of supply chain process integration capabilities, information technology infrastructure and government policy on supply chain performance of public universities in Kenya. It was hypothesized that the joint effect of supply chain process integration capabilities, information technology infrastructure and government policy on supply chain performance of public universities in Kenya is different from their individual effects. The study was guided by the resource based view (RBV). The study adopted a descriptive survey design. A self-administered questionnaire was distributed to 31 public universities in Kenya with a target of 62 respondents one from procurement and one from the information communication technology departments respectively. The response rate was 81 per cent. Descriptive statistics, correlation and regression techniques were used to analyze the collected data. The results of the study indicate that there is a joint effect of supply chain process integration capabilities, information technology infrastructure and government policy on supply chain performance of public universities in Kenya of $\mathrm{R}^{2}=0.688, \mathrm{~F}=34.586$, at $\mathrm{P}<$ 0.05 . The implication of the study is that policy makers and implementers have to formulate superior supply chain process integration capabilities, information technology infrastructure and government policy to achieve high levels of supply chain performance in public universities. This can build robust and agile end to end supply chains, policies, procedures, and practices for attainment of competitive advantages in operations.

Keywords: Supply chain process integration capabilities, information technology infrastructure, government policy, supply chain performance, public universities

DOI: $10.7176 / \mathrm{PPAR} / 10-11-06$

Publication date: November $30^{\text {th }} 2020$

\section{Introduction}

The business environments and the structures of current markets are highly dependent on service sector. This service industry has increased quickly due to the economic globalization making the sectors contribution to economic growth increasingly obvious, this, notwithstanding importance of the service sector as a driving force of GDP in developed and developing countries alike. Supply chain management concept is still immature in literature compared to manufacturing sector (Liu et al., 2017). There is significant lack of understanding of the concept of supply chain and the implementation of its practices in addition to the lack of studies that focused on how to model, manage establish measurements indicators for performance of the same service chains. Service supply chain structures are moving from linear to network forms which complicate evaluation of the same supply chains performance due to the averse amount of information of selecting performance indicators Leończuk (2016).

Literature defines Supply Chain Integration (SCI) as the degree of integration of core processes across organizational boundaries through improved communication, partnerships, alliances and cooperation. It also includes the application of new technologies to improve information flows and coordinate the flow of physical goods between supply chain partners (Asgari, Hamid \& Aleebrahim, 2017). Fawcett, Stanley, Stephen, Jones \& Amydee, (2012) aver that some organizations are more successful in achieving external integration than internal integration while others suffer from external integration issues (Asgari, Hamid, Aleebrahim 2017).

Kenyan public universities, just like other institutions of higher learning elsewhere in the world, are implementing various information systems to facilitate their operations and to enhance institutional management given their abilities to standardize, streamline operations, and integrate operational processes (Nyandiere et al., 
2012). There seem to be significant differences in strengths and weaknesses among private and public universities in capabilities of systems they have implemented. The public universities are noted to have weaker systems that are incapable of allowing seamless flow of information within their organizations sub-units (Nyandiere et al, 2012). There is less uptake of technology in the public universities, and due to the highly manual systems and processes (Ye \& Kankanhalli, 2013), there is less development of information technology infrastructure to support the process integration capabilities (Duffy, Jeyaraj, Farmer \& Sethi, 2015).

Successful supply chains require integrated supply chain management approach. This management strategy is concerned with linkages and integration with other partners to enhance supply chain relationships developed with upstream suppliers and downstream partners through enhanced networks, knowledge transfer and communication channels with suppliers. For process integration to succeed there is need to achieve a fit or match between supply chain process integration and information technology infrastructure to support groundbreaking efforts that are critical to augment the competiveness and performance of an organization (Tolmay, 2017). Studies have provided evidence concerning the positive impacts of SCI on performance either through explicit or implicit consideration (Pierre, Richard, Devinney, Yip, \& Gerry, 2015).

Resource Based View suggests that unique deployment patterns of unique resources and capabilities is the basis on which competitive advantage of a certain firm is built and can be a primary determination of superior performance. The resources and capabilities of an organization can be thought of as a platform from which the firm develops different products or services for several markets that enable the firm to develop a competitive advantage. This emphasis is on a firm's basic capability that includes coordination of different types of production knowledge, and the capability of integrating multiple technological flows (Rajapathirana \& Hui, 2018). Previous studies have investigated the influence of SCPI, information technology infrastructure and government policy, as single variables on performance of organizations performance singly. These studies did not focus on the joint effect of the variables on supply chain performance. This study advanced a cohesive model to scrutinize the joint effect SCPI, information technology infrastructure and government policy, on supply chain performance to depict a more comprehensive association of the variables.

\section{Literature Review}

Resources are stocks of available factors owned or controlled by a firm while capabilities are the firm's capacity to deploy resources. Resource Based View (RBV) assumes that firm's bundles of resources are heterogeneously distributed across different firms (Matopoulos, Barros \& Van der Vorst, 2015). They aver that RBV has since become one of the dominant contemporary approaches to the analysis of sustained competitive advantage. The argument is that no two companies are the same because they have had the same set of experiences, acquired the same assets and skills or developed the same cultures. This has led scholars to theorize that a firm achieves competitive advantage when the firms' resources are rare, valuable, or inimitable and non-substitutable (Chae, Olson, \& Sheu, 2014). The focus is on how competitive advantage is generated, sustained over time within specific firms. RBV perceives that unique deployment patterns of unique resources and capabilities, as the basis on which competitive advantage of a certain firm is built and can be a primary determination of superior performance.

There is consensus in the management conversations on the role of firm resources and capabilities in explaining why firms differ in the creation and sustenance of competitive advantage (Matopoulos, Barros \& Van der Vorst, 2015). They connote that resources are not valuable on their own but because they allow firms to develop and implement value-creating strategies that create advantages in particular markets. Resources and capabilities can be thought of as a platform from which the firm derives various products for various markets that enable the firm to develop competitive advantage. Chae, Olson, \& Sheu, (2014) emphasizes a firm's basic competence which includes coordination of different types of production knowledge, and the competence of integrating multiple technological flows. This has led to scholars such as Chae, Olson, \& Sheu (2014) to look for the uniqueness that an organization has that contributes to performance. Hence, issues like environment (market competition), internal factors, firm strategy, structure, system and people, competence and capabilities and assets size and financial capabilities have become the explanatory factors in explaining performance. Kamasak (2017) established that most RBV researchers choose to look within the enterprise and to the factor market conditions that the enterprise must contend with, to search for some possible causes of sustainable competitive advantages holding constant all external environmental factors.

Sanderson, Lonsdale, Mannion \& Matharu (2015) argued that the bonding effect of relationship-specific investments based on RBV can be one of the most important determinants of buyer-supplier relationships. Duffy et al., (2015) pondered that each firm is characterized by its own unique collection of resources of core competencies. Veerendrakumar, Narasalagi., \& Shivashankar, (2015) established that the source of competitive advantage is the creation and exploitation of distinctive capabilities that are difficult to creat and maintain, codify, make into recipes that are hard to copy, emulate, and cannot simply be bought off the shelf. Veerendrakumar, Narasalagi., \& Shivashankar, (2015) further established that there are three basic distinctive capabilities; corporate architecture, innovation and reputation. Duffy et al., (2015) identified the following propositions on distinctive 
capabilities; arm's length relationships that are associated with low asset specificity and low supplier competencies that can easily be bought off the shelf as there are many potential suppliers; internal contracts, which is an in-house provision associated with high asset specificity and core competencies; and partnership relationships that applies to assets of medium specificity and ascend in steps according to the distance of the complementary competencies as provided by external suppliers from the core competencies of a particular firm.

From the Resource-Based View, the focus of Supply Chain Management (SCM) research in recent years has shifted from the narrow operating efficiency considerations to the effective resources or capabilities development that emphasizes collaborative Research and Development (R\&D) and innovation (Jiguang \& Bing 2018). Collaborative R\&D and innovation reflects the characteristics of win-win cooperation in SCM which contributes to maximizing their mutual interests that benefit the whole supply chain (Aschhoff, 2018). Greater supply chain collaboration has important strategic significance to the boundary-spanning of a supply chain because they need to utilize the resources and knowledge of their partners to enhance innovation capacity that could not be accomplished solely by them (Festel, De Nardo \& Simmen, 2014). The systems are built upon the communication and trust mechanism and the benefit and risk sharing mechanism, This makes it possible for the collaborative R\&D of the supply chain to be launched successfully in a format of a series of detailed arrangements, such as clear divisions of labor, intellectual and intangible property ownership, cost-sharing, and opportunism prevention. Huo, Han \& Prajogo (2016) posit that RBV is relevant to the study of supply chain process integration and information technology infrastructure, because SCPI and IT are considered structure-related variables, as the internal process integration changes and defines the rules and routines that people need to follow. Hunt \& Davis, (2012) suggested that external relationships have to be internalized and be considered as a part of organizational structure. Duffy, et al., (2015) aver that integration in essence is the structure realignment that focuses on optimal resource configuration. The RBV is relevant because the purpose of supply chain process integration is to enhance allocation of resources within and across firms. Resources are the key input factors in the RBV and acquiring a unique bundle of resources is critical to a firm's success. According to (Duffy et al., (2015) superior performance achieved in supply chain activities relative to competitors, would explain how these activities can be supported by supplier-customer relationship management can contribute to the supply chain core.

Academicians have focused their research on supply chain process integration by heavily relying on undimensional supply chain relationships by examining collaborative relationships between manufacturers and their customers (Chopra \& Meindl, 2016). This finding established several flows across the supply chain in materials, information and finances (Lee, Chung, Lee, Gan, \& Chou, 2016). The measurement of performance has been very complicated given that different methods have been used. Performance studies in relation to SCI can be classified into three groups (These are the relation between internal SCI and performance, between external SCI and performance or both types of SCI with regards to performance.

Many research articles have argued and provided evidence concerning the positive impacts of SCI on performance either through explicit or implicit consideration (Pierre, et al., 2015). Hefu, Ke, Wei \& Hua (2016) investigated the impact of two different dimensions of supply chain integration on two aspects of firm performance in the emerging economy of China. In addition, the moderating effects of market orientation on the relationship between supplies chain integration and firm performance. This study determined that operational coordination is positively associated with operational performance and business performance. The results also provided empirical support for the moderating effects of market orientation on the association of supply chain integration and firm performance.

In a study Mikihisa \& Oji (2017) explored how firms' can realize continuous supply chain process improvement. The study proposed success factors of routine activities in the supply chain process improvement. Eight Japanese manufacturers were selected for the case studies. The firms were selected based on their supply chain process operation capabilities. The findings were that planning of supply chain process improvement depends on the existing stages of the firm's Supply Chain Management reform. In addition, even firms with high scores for supply chain process operation capabilities do not have supply chain performance systems. Information flow integration enables linkages internally between business units, supplier and customer linkages (Lee et al., 2016).

Omneya \& Rasha (2018) adduce that integration through efficient and effective flow of information eventually lead to better supply chain and individual firm's performance. Physical flow is the use of global optimization with supply chain partners to manage the materials and finished goods flow from source to ultimate consumer. Whenever there is integration between suppliers and their customers' internal processes, there is a reduction of costs and an improvement in product quality and general productivity of manufacturers through cost reduction, reliable deliveries, improved inventory and supplier management Physical flow integration contributes significantly to a firms performance and finally to the total supply chain members (Chul-hwan, 2018). Lee et al., (2016), posit that for workflow events to function well, it is imperative that the exchange of financial resources between a focal firm and its supply chain partners brings out financial flow integration.

The activities required to facilitate the flow of funds across the supply chain involves; invoicing of customers, 
paying suppliers and internal transfers which improves cash conversion cycle or cash-to-cash cycle through reduced days-in-inventory, shortened days-in-receivables and prolonged days-in-payables. Financial flow integration is essential for effective and efficient management of supply chain performance (Alexander Walker \& Naim, 2014). Tangpong, Michalisin, Traub, Melcher (2015) posit that the core behind SCM is the integration of internal processes with the suppliers and customers. Effective communication by use of internet, web-based systems enable inter-organizational communication which is considered as being frequent, genuine, and involves personal contacts between buying and selling personnel. This also involves inventory management, demand forecasting, customer and supplier relationship management (Yunus \& Kurniawan (2015) share views in support of information sharing in the supply chain.

The First view involves information sharing throughout the supply chain which is a necessary tool for having an effective and competitive supply chain because it allows the coordination of material flow (Lee \& Cho, 2014) and financial flow in the supply chain, which results in lower inventory costs across the chain and more efficient use of resources (Lee \& Cho, 2014). Information sharing leads to improved forecasting, demand planning and replenishment, and results to higher sales, improved inventory management and better understanding of demand hence reducing the bullwhip effect (Caridi, Moretto, Perego, \& Tumino 2014) Secondly, the benefits gained from information sharing is represented by determining what information to share and with whom is compared to the high costs associated with the information technology implementation and the issue of complexity.

Yunus \& Kurniawan (2015) assert that joint solutions to material problems and design issues in supply chain partners must commit and be willing to share sensitive design information that can be achieved through engineerto-engineer communication on design issues, in order to improve process capability, manufacturability, and performance without affecting profit margins. Jiguang \& Bing, (2018) connote that there are two types of information; operational information that include information shared on a daily basis related to sales, logistics activities such as delivery schedules, inventory levels, production schedules and order status help to reduce cycle time, inventory levels and improve service levels, and strategic information associated with sharing marketing, logistics resources planning, capacity planning and long-term forecasting information. Collaboration and planning for future logistics practices is improved across the supply chains for long-term competitiveness through this type of information (Veerendrakumar, Narasalagi., \& Shivashankar, 2015).

Jiguang \& Bing, (2018) opine that an efficient and effective information sharing platform is considered a critical component of a supply chain design which contributes to a better partnership and integration. This platform should be designed to enable the whole supply chain to share essential market and operational information, improve productivity, and reduce transaction cost and time-to-market. (Jiguang \& Bing (2018) aver that in a centralized information platform, partners of the supply chain will continuously update operational data required by the decision-making committee, monitor the critical situation as reflected by the updated data, and coordinate the daily operational schedule based on the information in the platform. Effective decision making is based on knowledge acquired and disseminated to diverse partners in the supply chain. Globally research has confirmed that converting knowledge resources into value requires a proper governance framework because knowledge is only valuable when it is put to proper use (Jiguang \& Bing 2018).

The governance framework for information sharing platform facilitates operations, monitors critical information, triggers responses, and manages knowledge. The framework enables supply chain partners to optimize their operations with improved returns to benefit all the partners thus further consolidating partnerships and moving the supply chain in a positive direction. In the RBV perspective organizational resources and capabilities underlie and determine a firm's capacity for innovation. These knowledge resources provide the necessary inputs for the development and exploitation of a firm's innovation activities to enable the firm adapt to the rapidly changing environment and create competitive advantage (Matopoulos, Barros \& Van der Vorst, 2015). The process of acquiring, storing of raw materials, components, and finished goods is referred to as material management (Qureshi, Iftikhar, Bhatti, Shams \& Zaman, 2013). The physical distribution relates to activities such as order processing, inventory deployment, storage and handling, and transportation. Material management (MM) enables efficient flow of raw materials and finished goods across the different functional units in the organization. Material flow needs to be synchronized in a way that prevents build-ups and interruptions of inventory (Qureshi et al., 2013).

Firms implement several practices and initiatives for synchronizing the flow of material with their suppliers and customers. According to Gualandris, Klassenb, Vachonb, \& Kalchschmidt (2015) firms that have a wellcoordinated flow of material enable them to deliver products to end customers in a timely, efficient and effective way. Several actors define financial flows to include both the upstream and downstream actors in the supply chain (Silvestro \& Lustrato, 2014). The downstream viewpoint of financial resources includes prices, invoices, and credit terms whereas the upstream resources include payments to suppliers and account payables (Lee et al., 2016). Financial flow was considered by some authors as a key element of the supply chain. The effective flow of financial resources between the focal firms and its suppliers and customers results in shorter cash-to-cash cycle by reducing days-in-inventory, shortening days-in-receivables and extending days-in-payables (Silvestro \& Lustrato, 2014). 
Researchers and practitioners have given much attention to the topic of information technology infrastructure. Information technology infrastructure is the extent to which a firm has established information technology capabilities for the consistent and high-velocity transfer and information sharing within and across the supply chain boundaries. Previous studies posit that information technology infrastructure comprises a group of shared, tangible information technology resources that enable present and future business applications (Turek, 2013).

In the current turbulent market environments, flexible information technology infrastructure can instantaneously deliver rapid results and support sustainable growth (Tiwari, Tiwari, and Samuel, 2015). Information technology infrastructure supports rapid data-driven innovation, knowledge-sharing, and relational coupling with supply chain partners and enables flexible processes often considered a primary goal of information technology application adoption, such as Enterprise Resource Planning (ERP) or Electronic Data Interchange (EDI). ICT impacts both internal process and external integration by increasing the flow of relevant information among process participants by shaping closer supplier and customer relationship. Based on a survey of 127 companies in China Peng, Quan, Zhang, and Dubinsky, (2016) empirically confirmed that a firm's capability to manage both internal and external business processes fully mediate the impact of information technology on performance.

According to Tina (2013) Johnson and Johnson Company faced new business pressures when large customers, such as Wal-Mart and K-mart, made new demands on the company basing on cost savings and just-in-time stock replenishment. The company's business and IT managers acted in partnership to develop a new set of information technology infrastructure capabilities that enabled the company to provide the necessary services for its large customers while reducing costs at Johnson and Johnson Company (Wagner and Bode, 2014). Charles Schwab focused on delivering customized information to its investors in a timely manner by using the company's information technology infrastructure and applications aligned with its business focus that had made Schwab became a full service beverage firm. Due to this, the firm was able to provide information and process transactions in meeting its business objectives.

Customers' were able to retrieve stock quotes and place orders via Schwab's Web site, which made the corporation to be an industry leader (Wagner and Bode, 2014). Tina, (2013) opines that the capability building processes and actions in firms tie information technology infrastructure capabilities with the development of customer management capability. Better information technology infrastructure capabilities enable firms to position their information technology assets and data and information services to capture information about customers as well as disseminate information to customers through the internet, virtual communities and personalized information channels (Deepak and Saji 2016). The perspective of an integrated information technology infrastructure enables consistent and real-time transfer of information between supply chain management related applications and functions that are distributed across partners. The integrated information technology infrastructures for supply chain management can be blended with inter-organizational processes to develop higher order capabilities for demand sensing, operations, workflow coordination, and global optimization of resources.

Information technology infrastructure capability offers the appropriate support for process by providing the reach and connectivity to design and manage processes that connect the firm with its customers. A high level of information technology infrastructure enables firms to design metrics and analytics to provide visibility into the real-time performance of various processes. The integration between the various processes and advance warnings about performance degradation in processes and finally a high level of information technology infrastructure capability enables faster and more responsive redesign and reconfiguration of processes to enable responses to changes in business conditions (Tiwari, Tiwari, and Samuel, 2015).

Information technology can be used as a tool for addressing challenges in handling diverse data and information (Tina, 2013). In developing economies like Kenya adoption of ICT can be an efficient way to remove barriers that hinder economic development. Literature illustrate that ICT has a major role in public management reform since it enhances the quality of public service and at the same time reduce time and cost of transactions. According to Ali and Sassi, (2016) e-government in public institutions helps in reducing corruption levels and realization of Millennium Development Goals (MDGs). From a purely economic point of view ICT adoption helps improve public productivity and efficiency together with good governance. Ali and Sassi (2016) argue that egovernment can enhance service delivery.

Internal integration involves cross functional teams that may bring together a carefully selected array of specialists who share information and make product, process, and manufacturing decisions, jointly and simultaneously (Otchere Annan, and Anin, 2013). Internal integration is defined as a process of inter-functional interaction, collaboration, coordination, communication and cooperation that bring functional areas together into a cohesive organization (Wagner and Bode, 2014). Organizations with a low internal integration strategy will achieve low level of external integration and organizations implementing the full internal integration strategy will have the highest levels of external integration (Otchere Annan, and Anin, 2013). External supply chain integration reveals two major areas of emphasis: Customer Integration (CI) and Supply Integration (SI). Supplier and Customer integration interactions and collaborations ensure an effective flow of products and services to customers. 
(Wagner and Bode, 2014). CI involves sharing demand information, help the manufacturer to understanding better the customer needs and to forecast better customer demand, as well as collaborative involvement of customers with respect to product design, provision of better quality products at lower cost and more flexibility in responding to customer demand (Tiwari et al., 2015).

The public universities in Kenya are incorporated through an Act of Parliament under the Universities Act, 2012 for governance and accreditation of universities. Universities in Kenya are regulated by the Commission for University Education (CUE) which is a sole regulatory which is the successor of the Commission of Higher Education that was established in 1986 by an Act of Parliament, University Act, CAP 210B. According to the Commission for University Education (CUE), 2017, Kenya has 31 accredited public universities. The public universities generate broader economic growth in terms of creation of employment opportunities, creation of innovation and diversification of the income generating paradigms through research. Universities nurture graduates, unlock and harness new knowledge, build cultural and political understanding. Universities being public entities usually get funds from government grants, donations, bursaries, students' fees and tuitions payments hence without an effective supply chain practice would lead to poor financial and operational performance.

Supply chain activities in the public universities continue to evolve both conceptually and organizational in order to enhance their performance (Lufunyo, 2013). According to Fourie and Poggenpoel (2017) performance is a contemporary issue that applies to all organizations both private and public and profit and non-profit organization and in order to be more effective and efficient in an ever-changing environment, the public universities have to reform. Supply chain performance is defined as the ability of the supply chain to deliver the right product to the correct location at the appropriate time at the lowest cost of logistics (Gunasekaran, Subramanianand Rahman 2015). The qualitative measures are customer satisfaction, flexibility, information and material flow integration, effective risk management, and supplier performance. Most studies agree that this is because of the lack of agreement on its levels and components (Zhang and Huo, 2013). There is emphasis on efficiency, transparency, accountability in university processes and operations in order to enhance organizational flexibility and excellence. There are indications that supply chain integration would add value to the operations hence promoting high organizational performance in public universities (Singh, Sohani, Marmat, 2013).

\section{Methodology}

This study adopted a positivism approach. Positivism involves theory testing and the key argument of positivist orientation is that the world exists externally, and that its properties should be measured through objective methods, rather than being inferred subjectively through sensation, replication or instinct (Hyett, Kenny, and Dickson-Swift, 2014). Positivists argue that true knowledge is scientific in character and describes interrelationships between real and observable phenomenon. Positivist orientation is related to the quantitative approach, a research strategy or general orientation to conduct research (Rahman, 2017). The study adopted descriptive survey design and a census of all 31 public universities in Kenya to collect relevant data which was used to determine the correlation between the variables of the study.

The target population consisted of heads of procurement and Information Communication Technology departments totaling to 62 respondents form all the public universities in Kenya. The census approach was justified since according to Saunders, Lewis and Thornhill, (2016), data gathered using census contributes towards gathering of unbiased data representing all individuals' opinions in the study population on a study problem.

A structured questionnaire was self-administered in the process of collecting data. A pilot, validity and reliability study was done. Instrument validation was achieved through validity and reliability measures. A pretest was done, on the basis of the pre-test response, the instrument was adjusted appropriately. Validity which indicates whether the instrument is testing what it should was done through examination of content to determine whether it covered a representative sample of the measurement items. Validity was assessed using expert opinion and informed judgment (Gujarati, Porter and Gunasekar, 2013).

The Cronbach Alpha was calculated to test for reliability. The Cronbach's Alpha coefficient was used to measure the internal consistency of measurement scales. This is a scale measurement tool, which is commonly used in social sciences to establish the internal consistency of items or factors within and among variables of study. Saunders, Lewis, and Thornhill, 2016) argues that an alpha coefficient of .700 or above is an acceptable measure. Information technology infrastructure had a Cronbach Alpha coefficient of .941 and supply chain performance of public universities had .934 this indicated that the data collected using the above mentioned instruments was reliable for analysis.

The multiple linear regression model used was;

$Y=\alpha+\beta_{1} X_{1}+\beta_{2} X_{2}+\beta_{3} X_{3}+\varepsilon$

$\mathrm{Y}=$ Supply chain performance of public universities

$\alpha=$ constant (intercept)

$\mathrm{X}_{1}=$ supply chain process integration capabilities

$\mathrm{X}_{2-}=$ information technology infrastructure 
$\mathrm{X}_{3=}$ government policy

$\beta_{1}, \beta_{2}, \beta_{3}$ are the coefficients

$\varepsilon$-is the error term

\section{Results and Discussions}

The study used both descriptive and inferential statistics for data analysis. Regression analysis was used to establish the relationship between the variables and to test the hypothesized relationship. The value of coefficient of determination $\mathrm{R}^{2}$ shows the degree or amount of variation in the dependent variable attributed to the predictor variable. The Beta values show the amount of change in the dependent variable attributable to the amount of change in the predictor variable, and the F ratio measures the model fit, or simply it is a measure of how well the equation line developed fits with observed data. The statistical significance of each hypothesized relationship was interpreted based on $\mathrm{R}^{2}, \mathrm{~F}, \mathrm{t}, \beta$ and $\mathrm{p}$ values.

Table 1: Regression Results of the Individual Effect of Supply Chain Process Integration Capabilities, Information Technology Infrastructure and Government policy on Overall Supply Chain Performance

\begin{tabular}{lllll}
\hline Model & $\mathbf{R}$ & $\begin{array}{l}\text { R } \\
\text { Square }\end{array}$ & $\begin{array}{l}\text { Adjusted } \\
\text { Square }\end{array}$ & $\begin{array}{l}\text { R Std. Error of the } \\
\text { Estimate }\end{array}$ \\
\hline 1 supply chain process integration capabilities & $.585^{\mathrm{a}}$ & .342 & .340 & .38402 \\
2 Information technology infrastructure & $.523^{\mathrm{a}}$ & .274 & .272 & .58386 \\
3 Government policy & $.580^{\mathrm{a}}$ & .336 & .335 & .55811 \\
4 Joint- supply chain process integration capabilities, .830 & .688 & .668 & .39410 \\
Information technology infrastructure, Government policy & & &
\end{tabular}

(a) ANOVA

\begin{tabular}{|c|c|c|c|c|c|}
\hline Model & & $\begin{array}{l}\text { Sum of } \\
\text { Squares Df }\end{array}$ & Mean S & & Sig. \\
\hline \multirow[t]{3}{*}{1 Supply chain process integration capabilities } & Regression & $37.526 \quad 1$ & 37.526 & 254.469 & $.000^{\mathrm{a}}$ \\
\hline & Residual & $72.260 \quad 49$ & .147 & & \\
\hline & Total & 109.78650 & & & \\
\hline \multirow[t]{3}{*}{2 Information technology infrastructure } & Regression & $47.032 \quad 1$ & 47.032 & 137.967 & $.000^{\mathrm{b}}$ \\
\hline & Residual & 124.76849 & .341 & & \\
\hline & Total & 171.80050 & & & \\
\hline \multirow[t]{3}{*}{3 Government policy } & Regression & $57.795 \quad 1$ & 57.795 & 185.546 & $.000^{\mathrm{b}}$ \\
\hline & Residual & 114.00549 & .311 & & \\
\hline & Total & 171.80050 & & & \\
\hline \multirow{3}{*}{$\begin{array}{l}\text { 4 Joint- supply chain process } \\
\text { capabilities, Information } \\
\text { infrastructure, Government policy }\end{array}$} & Regression & 116.1163 & 5.372 & 34.586 & .000 \\
\hline & Residual & 107.30047 & .155 & & \\
\hline & Total & 223.41650 & & & \\
\hline
\end{tabular}

Model

1 Constant) upply chain process integration capabilities

2 Constant Information technology infrastructure

\begin{tabular}{|c|c|c|c|c|c|c|}
\hline \multicolumn{2}{|c|}{$\begin{array}{c}\text { Unstandardized } \\
\text { Coefficients }\end{array}$} & \multicolumn{3}{|c|}{$\begin{array}{c}\text { Standardized } \\
\text { Coefficients }\end{array}$} & \multirow[t]{2}{*}{$\mathrm{t}$} & \multirow[t]{2}{*}{ Sig. } \\
\hline B & Std. Error & & Beta & & & \\
\hline 1.335 & .108 & & & & 12.333 & .000 \\
\hline .473 & .030 & & & .585 & 15.952 & .000 \\
\hline 1.109 & .170 & & & & 6.522 & .000 \\
\hline .686 & .058 & & & .523 & 11.746 & .000 \\
\hline 1.614 & .111 & & & & 14.536 & .000 \\
\hline .561 & .041 & & & .580 & 13.622 & .000 \\
\hline 1.656 & .596 & & -2.778 & .008 & & .008 \\
\hline .741 & .188 & .383 & 3.933 & .000 & .700 & 0.0429 \\
\hline
\end{tabular}

3 Constant Government policy (Constant)

capabilities

4 Joint- supply chain process integration capabilities, Information technology infrastructure, Government policy

a. Dependent Variable: Supply Chain Performance

b. Predictors: (Constant), Supply Chain Process Integration Capabilities, Information Technology Infrastructure, Government Policy 
The regression results presented in Table 1 show that the influence of supply chain process integration capabilities on supply chain performance was significant $\left(\mathrm{R}^{2}=0.342, \mathrm{~F}=254.46, \mathrm{P}<0.05\right)$ implying that supply chain process integration capabilities explains $34.2 \%$ of variation in supply chain performance while the other $65.8 \%$ is explained by other factors not considered in this study.

The regression of supply chain process integration capabilities on supply chain performance is significant with $(\mathrm{P}<0.05)$ and $\mathrm{F}$ ratio $(254.46)$. The co-efficient $\beta$ is also significant $(\beta=0.473, \mathrm{t}=15.952, \mathrm{P}<0.05)$ suggesting that when supply chain process integration capabilities change by one per cent, it leads to a $47.3 \%$ change in supply chain performance. Further information technology infrastructure also showed significant influence on supply chain performance $\left(\mathrm{R}^{2}=0.274, \mathrm{~F}=137.97, \mathrm{P}<0.05\right)$ and strategy $\left(\mathrm{R}^{2}=0.336, \mathrm{~F}=185.546\right.$, $\mathrm{P}<0.05)$. This implies that both information technology infrastructure and government policy are significant in explaining supply chain performance. The test for joint effects was performed through a separate analysis to establish the combined influence of supply chain process integration capabilities, information technology infrastructure and government policy on supply chain performance.

The regression results in table 1 show that the joint influence of supply chain process integration capabilities, information technology infrastructure and government policy on supply chain performance was significant $\left(\mathrm{R}^{2}\right.$ $=0.688, \mathrm{~F}=34.586, \mathrm{P}<0.05)$. The results suggest that jointly, supply chain process integration capabilities, information technology infrastructure and government policy explain $(68.8 \%)$ of variation in supply chain performance, while the remaining $31.2 \%$ is explained by other factors not considered in the study. The F ratio shows that the regression of supply chain process integration capabilities, information technology infrastructure and government policy on supply chain performance is statistically significant at $(\mathrm{P}<0.05)$. It is clear from the value of $\left(\mathrm{R}^{2}=.668\right)$ and $\mathrm{F}$ ratio that the regression model was fit for use in the analysis.

The joint effect was significant $\left(\mathrm{R}^{2}=0.688, \mathrm{~F}=34.586, \mathrm{P}<0.05\right)$. In view of this finding, the hypothesis that there is a joint effect of supply chain process integration capabilities, information technology infrastructure and government policy on supply chain performance of public universities in Kenya was supported. This is consistent with Deepak \& Saji (2016) who argue that the implementation of the ERP system has a positive effect on organizational performance and Affes, (2016) in his study on determinants of the implementation of ERP on the performance of the firms in Tunisia.

\section{Conclusion and Recommendation}

The study sought to determine the joint effect of supply chain process integration capabilities, information technology infrastructure, and government policy on supply chain performance of public universities in Kenya. The results indicate that there is a joint effect of supply chain process integration capabilities, information technology infrastructure and government policy on supply chain performance of public universities in Kenya. In view of this finding, the hypothesis that there is a joint effect of supply chain process integration capabilities, information technology infrastructure and government policy on supply chain performance of public universities was supported.

The implication of the study is that policy makers and implementers have to formulate superior supply chain process integration capabilities, information technology infrastructure and government policy to achieve high levels of supply chain performance in public universities. This can help in building robust and agile end to end supply chain systems, policies, procedures, guidelines and practices for the attainment of competitive advantages in operations.

The study has contributed to the existing body of knowledge in the area of supply chain management with emphasis on the role of supply chain process integration capabilities, information technology infrastructure and government policy with a bearing on supply chain management integrative practices in public universities.

\section{References}

Abdolshah M. (2013). A Review of Quality Criteria Supporting Supplier Selection. Journal of Quality and Reliability Engineering Volume 2013 (2013), Article ID 621073, 9

Affes H. (2016). The Determinants of the Implementation of ERP according to Management Control System and the Global Performance of the Firm: Case of Tunisia. J Glob Econ 4:201. doi: 10.4172/2375-4389.1000201.

Alexander, A., Walker, H., \& Naim, M. (2014). Decision theory in sustainable supply chain management: A Literature review, supply chain management: An International Journal. Vol.19 No. 5/6, pp. 504-522.

Ali B M \& Sassi S (2017). The role of ICT Adoption in Curbing corruption in developing countries. Springler International Publishing AG 2017. Available at www. http://DOI 10.1007/978-3-319-56523-1_4

Aschhoff Nils. (2018) Citizens Differ from Organizations: Modeling a Specific Citizen-Centered Collaborative Capacity. International Journal of Public Administration 41(4), 284-296.

Asgari A, Hamid ABA, Aleebrahim N (2017) Supply Chain Integration: A Review and Bibliometric Analysis. Int J Econ Manag Sci 6: 447. doi: 10.4172/2162-6359.1000447.

Caridi, M., Moretto, A., Perego, A. \& Tumino, A., (2014). The benefits of supply chain visibility: A value 
assessment model”, International Journal of Production Economics, 151(May), pp1-19.

Chae, Bongsug (Kevin), Olson David \& Sheu Chwen. (2014). The impact of supply chain analytics on operational performance: a resource-based view, International Journal of Production Research, 52:16, 4695-4710, DOI: 10.1080/00207543.2013.861616.

Chopra Sunil., \& Meindl Peter (2016), Supply chain management: strategy, planning, and operation, $\left(6^{\text {th }} \mathrm{ed},\right)$, New Delhi, Pearson Prentice Hall.

Chul-hwan Han (2018). Assessing the Impacts of Port Supply Chain Integration on Port Performance. The Asian Journal of Shipping and Logistics 34(2) (2018) 129-135.

Deepak Dahiyaand Saji K. Mathew. (2016).IT assets, IT infrastructure performance and IT capability: a framework for e-government", Transforming Government: People, Process and Policy, Emerald Group Publishing Limited, 10 (3), 411-433.

Duffy K. P., Jeyaraj A., Farmer B.M., \& Sethi V. (2015). Organizational Engagement with Supply Chain Integration: Achieving a Tangible Strategy. Journal of Information Technology \& Software Engineering, Volume 5, Issue 1

Fawcett, Stanley E., Stephen L., Jones, \& Amydee, M. (2012). Supply chain trust: The catalyst for collaborative innovation. Business Horizons, 55(2), 163-178.

Festel Gunter, De Nardo Mikko., and Simmen Timo (2014).Outsourcing of pharmaceutical Manufacturing- a Strategic Partner Selection Process", October 2014, International Journal of Operations and Production Management, 35(9)

Fourie David and Poggenpoel Wayne. (2017). Public sector inefficiencies: Are we addressing the root causes? South African Journal of Accounting Research, 31:3, 169-180.

GoK Commission for University Education (CUE). (2017). Status of Universities in Kenya. Available at: http://www.cue.or.ke/services/accreditation/status-of-universities.

Gualandris Jury, Robert D. Klassenb, Stephan Vachonb\& Matteo Kalchschmidt. (2015). Sustainable evaluation and verification in supply chains: Aligning and leveraging accountability to stakeholders, Journal of Operations Management, Volume 38, September 2015, Pages 1-13.

Gujarati Damodar, Porter Dawn, and Gunasekar Sangeetha. (2013).Basic Econometrics, $5^{\text {th }}$ ed, New Delhi, Tata McGrawHill Education. Pvt Ltd

Gunasekaran Angappa, Subramanian Nachiappan., and Rahman Shams(2015). Supply chain resilience: role of complexities and strategies. International Journal of Production Research, 53, (22), 6809-6819

Hefu Liu, Ke Weiling, Wei KK, \& Hua Zhongsheng (2016), "Effects of Supply Chain Integration and Market Orientation on Firm Performance: Evidence from China", International Journal of Operations \& Production Management, 322346.Availablefrom:https://www.researchgate.net/publication/259187620_Effects_of_supply_chain_inte gration_and_market_orientation_on_firm_performance_Evidence_from_China.

Huo Baofeng, Han Zhaojun \& Prajogo Daniel .(2016).Antecedents and consequences of supply chain information integration: a resource-based view", Supply Chain

Hyett, N., Kenny, A., and Dickson-Swift, V. (2014). Methodology or method? A critical review of qualitative case study reports. International Journal of Qualitative Studies on Health and Well-Being, 9, 10.3402/how. v9.23606

Jiguang Wang \& Bing Ran, (2018), Sustainable Collaborative Governance in Supply Chain, Sustainability, 10, (1), $1-17$.

Kamasak Rifat, (2017) "The contribution of tangible and intangible resources, and capabilities to a firm's profitability and market performance", European Journal of Management and Business Economics, Vol. 26 Issue: 2, pp.252-275, https://doi.org/10.1108/EJMBE-07-2017-015.

Laws of Kenya University Act, CAP 210B Revised Edition 2012 [1986] Published by the National Council for Law Reporting with the Authority of the Attorney-General www.kenyalaw.org.

Leończuk, Dorota. (2016) "Categories of supply chain performance indicators: an overview of approaches "Business, Management and Education, Vol. 14, No.1, pp.103-115.

Liu, Weihua., Bai, Enze., Liu, Liwei and Wei, Wanying. (2017) "A Framework of Sustainable Service Supply Chain Management: A Literature Review and Research Agenda" Sustainability, Vol.9, p 421.

Lufunyo, H. (2013). Impact of public sector reforms on service delivery in Tanzania. Journal of Public Administration and Policy Research, 5(2), 26-49.

Matopoulos, Aristides., Barros Ana., \& Van der Vorst Jack. J.G.A.J. (2015). Resource-efficient supply chains: A research framework, literature review and research agenda, Supply Chain Management. An International Journal, Vol. 20 Issue 2 pp. 218 -236.

Mikihisa Nakano \& Nobunori Oji (2017) Success factors for continuous supply chain process improvement: evidence from Japanese manufacturers, International Journal of Logistics Research and Applications, 20:3, 217-236, DOI: 10.1080/13675567.2016.1219704. 
Nyandiere, C., Kamuzora, F., Lukandu, I. A., \& Omwenga, V. (2012). Implementing enterprise systems for management. A Case of Kenyan Universities: Computer technology and application 3 (2012) 558-563.

Omneya Kandil \& Rasha Abd El Aziz. (2018).Evaluating the supply chain information flow in Egyptian SMEs using six sigma: A case study, International Journal of Lean Six Sigma, 10-2016-0066 available at www.emeraldinght https://doi.org/10.1108/IJLSS.

Otchere, A.F., Annan, J. and Anin, E.K. (2013). Achieving Competitive Advantage through supply chain integration in the cocoa industry: A case study of Olam /Ghana Limited and Produce Buying Company Limited. International Journal of Business and Social Research (IJBSR).3(2), pp.131-145.

Pierre, Richard J., Timothy M. Devinney, George S. Yip., \& Gerry Johnson. (2015). Measuring Organizational Performance as a Dependent Variable:

Peng, J., Quan, J., Zhang, G., and Dubinsky, A.J. (2016). Mediation effect of business process and supply chain management capabilities on the impact of IT on firm performance: evidence from Chinese firms. International Journal of Management, 36 (1), 89-96.

Qureshi Muhammad Imran, Iftikhar Mehwish, Bhatti Mansoor Nazir, Shams Tauqeer \& Zaman Khalid .(2013).Critical elements in implementations of just-in-time management: empirical study of cement industry in Pakistan, Springerplus, 2: 645.

Rahman Md Shidur (2017) The Advantages and Disadvantages of Using Qualitative and Quantitative Approaches and Methods in Language "Testing and Assessment" Research: A Literature ReviewJournal of Education and Learning; Vol. 6, No. 1

Rajapathirana Jayani R.P. \& Hui Yan. (2018). Relationship between innovation capability, innovation type, and firm performance, Journal of Innovation \& Knowledge Volume 3, Issue 1, January-April 2018, Pages 44-55, available at www. https://doi.org/10.1016/j.jik.2017.06.002.

Saunders, M., Lewis, P., and Thornhill, A. (2016). Research methods for business Student: (7 ${ }^{\text {th }}$ ed), L.E.G.O. S.p.A., Italy.

Silvestro, R. \& Lustrato, P. (2014), "Integrating financial and physical supply chains: the role of banks in enabling supply chain integration”, International Journal of Operations and Production Management, 34(3), pp298324.

Singh Ram Janm, Sohani Nagendra, Marmat Hemant. (2013). Supply Chain Integration and Performance: A Literature Review. Journal of Supply Chain Management Systems 2 (1) January 2013.

Tangpong Chanchai, Michalisin Michael D. , Traub Rodney D, Melcher Arlyn J. , (2015) "A review of buyersupplier relationship typologies: progress, problems, and future directions", Journal of Business \& Industrial Marketing, Vol. 30 Issue: 2, pp.153-170, https://doi.org/10.1108/JBIM-10-2012-0193.

Tina Bjørnevik Aune. (2013). Managing Suppliers in Business Networks: Exploring Innovation, Capability Development, and Network Pictures, October 2013

Tiwari, A.K. Tiwari, A., and Samuel, C., (2015). Supply chain flexibility: a comprehensive review. Manag. Res. Rev. 38 (7), 767-792.

Tolmay, A.S., (2017), 'The correlation between relationship value and business expansion in the South African automotive supply chains', Journal of Transport and Supply Chain Management 11(0), a245. https://doi.org/10.4102/jtscm.v11i0.245.

Turek, B., (2013). Information systems in supply chain integration and management. Retrieved from http://www.ehow.com/ info_8337099_information-supply-chain-integration-management.html

Veerendrakumar M., Narasalagi., \& Shivashankar K. (2015). Exploratory Study on Achieving Sustainable Competitive Advantage through Supply Chain Innovation for Strengthening Organizational Performance. International Journal of Economics and Management Sciences, 2015, Volume 4, Issue 3, ISSN:2162-6359 IJEMS.

Wagner Stephan M. and Bode Christoph. (2014) Supplier relationship-specific investments and the role of safeguards for supplier innovation sharing. Journal of Operations Management 32:3, 65-78.

Ye Jonathan \& Kankanhalli Atreyi. (2013). Exploring innovation through open networks. A review and initial research questions, IIMB Management Review (2013) 25, 69-82

Yunus,E. N. \& Kurniawan T., (2015). Revealing Unsuccessful Collaboration: A Case of Buyer-Supplier Relationship in the Pharmaceutical Industry Supply Chain Forum: An International Journal Volume 16, 2015 - Issue 2.

Zhang, M., and Huo, B. (2013). The impact of dependence and trust on supply chain integration: International Journal of Physical Distribution and Logistics Management, 43(7), 544-563. 